Research.

\title{
THE EFFECT OF NUMBER OF MEETINGS OF THE BOARD OF COMMISSIONERS, INDEPENDENT COMMISSIONERS, AUDIT COMMITTEE AND OWNERSHIP STRUCTURE UPON THE EXTENT OF CSR DISCLOSURE
}

\author{
Raphita Fauzyyah ${ }^{1,{ }^{*}}$, Sistya Rachmawati ${ }^{2}$ \\ 1,2 Department of Accounting, Trisakti University, Jakarta, Indonesia. \\ raphita_fauzyyah@gmail.com (R. Fauzyyah), sistya_r@yahoo.com (S. Rachmawati)
}

*Corresponding author

Received: October 20, 2018; Accepted: November 12, 2018; Published: December 31, 2018

To cite this article: Raphita Fauzyyah and Sistya Rachmawati. The Effect of Number of Meetings of The Board of Commissioners, Independent Commissioners, Audit Committee and Ownership

Structure upon The Extent of CSR Disclosure, The Accounting Journal of BINANIAGA, Vol. 03, No. 02, December 2018, pp. 41-54.

\begin{abstract}
This study aims to investigate the characteristics of corporate governance that affect the level of Corporate Social Reponsibility (CSR) disclosure in the firms that have business operations in the manufacturing field in Indonesia. Characteristics of the corporate governance used in this study are the number of meetings conducted by the board directors, independent commissioners, audit committee, managerial along with foreign that have ownership, and ownership concentration. The level of work on CSR disclosure was measured by using company's social disclosure index (or later will be referred to as CSDI) based on standard used, namely Global Reporting Initiative (or later to be discussed as GRI) which will report standard items and then disclose the items in the firm's annual report. This study also used the levels of the firm's board commissioners, the composition or arrangement of women in the board, public along with institution ownership, and the control variables of this study was environment performance. The populations used in this study were firms that run business in the manufacture fieldwork sector that registered in Indonesian Stock Exchange (or known as IDX) in the 2014-2017. This disquisition using the method sampling purposive, the total population was reduced to 88 annual reports of firms that run mining business to be sampled in this research. The technique of data analysis used multiple regression method to determine whether there are relationship owned by the characteristics of corporate governance with CSR disclosure. The conclusion of the disquistion showed that composition of managerial ownership does not have significant and positive influence on the extent or level of CSR. The outcomes of the investigations also show that the two control variables have a significant influence on the extent or level of CSR.
\end{abstract}

Key words: audit committee, corporate social responsibility, ownership structure, board characteristics, composition of women on board, and environment performance

\section{INTRODUCTION}

A company was established to run a business in order to reach the profit and to expand the business of the company. This objective is to increase the prosperity of shareholders. And it could only be achieved effectively and efficiently by maximizing the organization value. The company has been encountering a very difficult challenge against

Raphita Fauzyyah and Sistya Rachmawati. The Effect of Number of Meetings of The Board of Commissioners, Independent Commissioners, Audit Committee and Ownership Structure upon The Extent of CSR Disclosure 
the modern technology and critical people about the information published. The company is not only applying the activities and making profit, but also solving the related social problem, or the company itself has created the related problem if there is not any possibility to get either short-term or long-term potential profit (Oktariani \& Mimba, 2014) The activities that have been done by an entity can give different effects, though it has the same operation it is affecting the corporate social responsibility of the entity. There is a difference of CSR at each organization which is CSRD or corporate social responsibility disclosure. The entity having a strong level of specific character will create social effect upon the people and will give full social responsibility (R.A. Sari, 2012).

\section{LITERATURE REVIEW AND HYPOTHESIS DEVELOPMENT}

\section{Corporate Governance}

The Corporate Governance described in this research is the combination of agency theory and stewardship. Stewardship theory is developed based on the philosophy of human behavior, basically human being is a man that can be relied on, do something with full of responsibility, honesty and integrity for others. According to the description of Murwaningsari (2009), this theory has described actually the management can be trustworthy running the responsibility for the purpose of the stakeholders and especially the shareholders. Executing the management responsibilities, the company has to make sure that corporate governance is applying the five principles of GCG which is transparency, accountability, responsibility, interdependency, naturally and egality in order to achieve the company continuity by focusing to other parties concerned.

\section{Number of the Meetings of Board of Commisioners}

Board of commissioners' meeting which is making decision in the entity can be the reason to measure this writing by identifying number of meetings conducted. When the board of commissioners has organized too many meetings, then the function of good supervision of the commissioners is required to evaluate the decisions that will be made by board of directors. Periodic board of commissioners' meeting will decrease the level of cheating or deception. Because routine meeting of board of commissioners will give the suggestion how to solve the crucial problem specifically about the quality of financial reporting (Marsha \& Ghozali, 2017)

\section{Independent Commissioners}

In the research of Budi (2013), board of commissioners is consisting of two parts which is independent commissioners and non-independent commissioners. Independent commissioners are not from the affiliated party, but non-independent commissioners are from the affiliated party. The affiliated party is a group or class having business connection with or the family of the entity shareholders, member of board of directors or other board of commissioners.

\section{Audit Committee}

Referring to Septiana, Hidayat \& Sulasmiyati (2016), audit committee is a committee created by the board of commissioners of the registered entity. Appointment and dismissal of the audit committee members can be done by board of commissioners of the entity. Responsibility and duties of the audit committee are useful to perform any investigations and crucial investigation to manage the registered organization. Three tasks of the audit committee are (1) financial report, (2) corporate governance, and (3) supervising the company.

Raphita Fauzyyah and Sistya Rachmawati. The Effect of Number of Meetings of The Board of Commissioners, Independent Commissioners, Audit Committee and Ownership Structure upon The Extent of CSR Disclosure 


\section{Managerial Ownership}

Referring to Budi (2013) managerial ownership is the condition where the managers are having some shares of the entity, in this case the manager is also the shareholders of the entity. The bigger the proportion of the managerial ownership at the entity, the higher the performance of the entity is (Murwaningsari \& Rachmawati, 2017).

\section{Expatriate / Foreign Ownership}

In the research of Wiranata \& Nugrahanti (2013), foreign/expatriate ownership means that foreign party (institution or individual) having a certain number of shares of the entity in Indonesia. Foreign ownership of the entity has indicated an optimal performance.

\section{Ownership Concentration}

Referring to Jenny, L (2012) ownership concentration is divided into two classification of ownership structures; closely held ownership and dispersed ownership. Leo defined that concentration of shares ownership has affected the disclosure of finance report and according to his research, the company which its shares ownership is closely held by the insider or controlling shareholders are not very interested in the disclosure of it since they can get the information directly as they have an access to it.

\section{The size of Board of Commissioners}

The size of board of commissioners is a method to control or to direct the management of the company (Anjani and Rahardja, 2013) Board of commissioners is in charge of supervising and giving a direction or suggestion to board of directors. Anjani and Rahardja (2013) have proven that number of members of commissioners will ease the entity to control the CEOs and the function of supervision will be more effective.

\section{Proportion of Women in the Board of Commissioners}

The company which is having women in the board of commissioners has tended to have better management than the company having only a few women or having none. (Marsono, 2014) indicated that the proportion of women in the board of commissioners has tended to motivate others to join the meeting of board of commissioners. So that, it makes board of commissioners more modern rather than the one which is homogenous.

\section{Public Ownership}

Public ownership of the shares is the percentage of shares circulated in public (Prayoga \& Almilia, 2013). Public ownership is people owned the shares (not a significant institution) upon the shares of private company. The pattern of company's ownership is also the structure of shares ownership which is the comparison between total shares of the outsider ownership and the total shares of the insider ownership or management (Prayoga \& Almilia, 2013).

\section{Institutional ownership}

Institutional ownership is the shares owned by the financial institution, such as, pension company, banking, funds, and management assets insurance (Kusuma, Rusli Tanjung \& Darlis, 2014). But Bushee (Hendratni et al, 2018) has proven that the institutional ownership has been running the function of controlling to help the managers not to make any decision accidentally that can jeopardize the company in the long- term period.

\section{Environmental Performance}

Retno and Wahidahwati (2017) in their research have mentioned that the performance of environment at work is the condition of work which is able to create a

Raphita Fauzyyah and Sistya Rachmawati. The Effect of Number of Meetings of The Board of Commissioners, Independent Commissioners, Audit Committee and Ownership Structure upon The Extent of CSR Disclosure 
good or geen environment at work. In order to make it happen, it has to be supported by the procedure how to perform an environmental performance. The Environmental performance is the measurement of the environment management related to the supervision upon the environment sector, and the result of the measurement has to be decleared obviously.

\section{CSR}

Referring to (Ibrahim et al., 2015) discussing about the social responsibility (CSR) is based on the opinion that the existence of a business unit is related to the surrounding environment roles. And, the activity of each entity will affect the environmental factors which is human quality, society and each individual person. CRS is the result of the consideration that an entity is not only responsible for economic elements which is profit, but also, it has to see the social feedback. This idea has identified that if the entity is only focusing on the financial matter, it will not guarantee that the entity will be developing in the future.

\section{Hypothesis Development}

1. The Impact of number of meetings of board of commissioners upon the extent of CSR Disclosure.

The way how board of commissioners determining the action to be done related to the policy running the company or entity is to conduct a meeting among board of commissioners. The execution of a meeting is based on the idea collected and discussion altogether. Anugerah \& Dewayanto (2012) declared that periodic routine meeting that has been done will improve the effectiveness of their supervision. Based on the description aforementioned, an overall disclosure of CSR has to be done because it is the board of commissioner's responsibility.

$\mathrm{H} 1$ : Number of meetings of board of commissioners has affected the disclosure of Corporate Social Responsibility

\section{The Impact of independent commissioners on the extent of CSR Disclosure}

The independence of commissioners is really needed in order they can put priority running the business of the entity instead of their interests (Anugerah \& Dewayanto, 2012). As described by other parties which are not affiliated with, the optimum supervision can only be done by the proper independent commissioners.

$\mathrm{H} 2$ : Independent commissioners have impacted positively on the extent of corporate social responsibility disclosure.

\section{The impact of Audit Committee on the extent of CSR disclosure}

Paramita \& Marsono (2014), defined that developing an audit committee, it has to recruit significant independent persons which can reduce the agency cost, and can improve internal supervision, so that, the quality of CSR disclosure will be better.

H3: Audit committee has positively impacted on the extent of corporate social responsibility disclosure.

\section{The Impact of Managerial Ownership on the extent of CSR Disclosure}

Referring to Swandari \& Sadikin (2016), Managerial ownership has not impacted on the extent of CSR disclosure, because the managers who have taken their profit for their own purpose will make the company suffer of financial lose, and other stakeholders.

H4: The Managerial ownership has not impacted on the extent of corporate social responsibility disclosure.

Raphita Fauzyyah and Sistya Rachmawati. The Effect of Number of Meetings of The Board of Commissioners, Independent Commissioners, Audit Committee and Ownership Structure upon The Extent of CSR Disclosure 


\section{The Impact of Foreign Ownership on the Extent of CSR Disclosure}

In the research of Paramita \& Marsono (2014) describing that the entity of multinational sector which is the foreign ownership will see the profit of shareholders based on home market (operational place) that has provided a long-term expectation. And Corporate Social Responsibility has to be described properly to demonstrate that the entity is fully concerned about public or society.

H5: Foreign ownership has positively impacted on the extent of corporate social responsibility disclosure.

\section{The Impact of Ownership Concentration on the Extent of CSR Disclosure.}

The problems occurred between the managers and the shareholders can be avoided by the ownership concentration. It has described on the research of Fitri (2012) indicated that the concentration of shares ownership is an internal control upon the managers who will make policies of the company. Marsha and Ghozali (2017) determined that ownership concentration is not positively and significantly demonstrating the extent of the disclosure.

H6: Ownership Concentration has negatively impacted on the extent of corporate social responsibility disclosure.

\section{RESEARCH METHOD}

\section{Dependent Variable}

Technics of the research analysis has applied content analysis method as the measurement of the observation on the item existed on the GRI information provided on the yearly report. However, on GRI, some elements discussed having the total of 91 per item which is the perspective of economy, manpower, environment, human rights, work environment, society and product. If there is not any item indicated on the report, then the value of the score is " 0 ", but, if an item is indicated then the value given is ' 1 '. Index disclosure is applied to figure out the extent of CSR disclosure. Nevertheless, the Index is calculated by dividing the total item of information offered by the total of all items. So that, the disclosure of CSR is measured by CSDI proxy. The equation of CSDI is as follows (Marsono, 2014).

$\mathrm{CSDI}=\underline{\text { Total of CSR mandatory item according to GRI which is disclosured by company }}$

Total item of CSR information required

\section{Independent Variable}

\section{Number of board commissioners' meetings}

Periodic and consistent meeting can increase the quality of board of commissioner's performance to supervise the job being done by the management and it can develop new ideas related to the regulation and decision produced by the management. The calculation of board of commissioner's meetings has applied the ratio (Zahra, et.al. 2016:3326).

Frequency of board commissioners' meetings $=\Sigma$ Frequency of board commissioners' meetings in a year.

\section{Independent Commissioners}

Measuring the independent commissioners as the variables of this writing is applying the following formulation (Paramita and Marsono, 2014:7):

Independent commissioners $=$ Total members of independent commissioners

Total all members of board commissioners in the company

Raphita Fauzyyah and Sistya Rachmawati. The Effect of Number of Meetings of The Board of Commissioners, Independent Commissioners, Audit Committee and Ownership Structure upon The Extent of CSR Disclosure 


\section{Audit Committee}

Referring to Saifi and Sarafina (2017) identified that calculating the independent audit committees by looking for the ratio of independent commissioners out of the total members of audit committee:

Audit committee $=\underline{\text { Independent commissioners in the audit committee }}$

\section{Managerial Ownership}

$$
\text { Total Audit Committee }
$$

Managerial ownership in the entity which is quite big has indicated that the management performance is better for all stakeholders, including the management which is the shareholders of the entity. This variable is calculated by this ratio (Marsono, 2014):

Managerial ownership $=$ Proportion of the shares owned by the management Total of the shares circulated

\section{Foreign ownership}

CSR disclosure of an entity is mostly affected by the level of foreign ownership, because foreign party is considered to be the focus of CSR disclosure description. The measurement of foreign ownership is applied the following ratio (Wiranata \& Nugrahanti, 2013).

$$
\text { Foreign Ownership }=\frac{\text { Total shares of foreign party }}{\text { Total shares circulated }} \times 100 \%
$$

\section{Ownership Concentration}

Ownership concentration is measured by the majority of shares owner

Ownership concentration $=\underline{\text { Total of majority shares ownership }} \quad \times 100 \%$

\section{Control variable}

$$
\text { Total of company's shares }
$$

\section{Size of Board of Commissioners}

Anggraini and Taufik (2017) identified that big numbers of members of board commissioners will make them easier to do the process of controlling the CEO and their supervision will be optimum. The size of board of commissioners is measured by the total of all components of the members of company's board of commissioners (Marsono, 2014).

\section{Proportion of Women in the Board of Commissioners}

The management of business organization will be more success if it involves women to be a part of the board. An entity or organization that has involved only a few women or none, it tends to be weak (Marsono, 2014). The calculation of women proportion in the board of commissioners is as follows (Marsono, 2014):

Proportion of women in the board of commissioners $=\underline{\text { Total of women commissioners }}$

$$
\text { Total member of company's board of commissioners }
$$

\section{Public Ownership}

The structure of public ownership can be identified as ownership of the shares which is the comparison between the shares owned by the internal management party(insider) and total of the shares owned by external party (outsider) (Prayoga \& Almilia, 2014). Shares ownership of the public is measured by the following ratio (Paramita and Marsono, 2014).

Public ownership $=$ Proportion of the shares owned by the public

$$
\text { Total of the shares published }
$$

Raphita Fauzyyah and Sistya Rachmawati. The Effect of Number of Meetings of The Board of Commissioners, Independent Commissioners, Audit Committee and 


\section{Institutional Ownership}

Referring to Wiranata \& Nugrahanti (2013), the variable of the institutional ownership will be calculated based on the ratio of total of the shares kept by the institutional party and the total shares of the entity distributed:

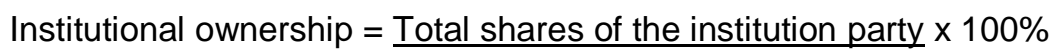
Total of the shares distributed

\section{Environmental Performance}

Environmental Performance is measured by a Method which is Program Evaluation of the Level of Environmental Management at the company or PROPER. The indicators refer to the scientific research of Retno and Wahidahwati (2017). The level of the entity performance in the program of PROPER is classified into 5 colours of the level with orderly scoring, as follows (Wiranata \& Nugrahanti, 2013):

Table 1

Scoring level of company's management performance in PROPER Data Analysis Method

\begin{tabular}{|c|c|c|c|}
\hline Level & Color Level & Status & Score \\
\hline Level I & gold & The best & 5 \\
\hline Level II & green & Very good & 4 \\
\hline Level III & blue & Good & 3 \\
\hline Level IV & red & bad & 2 \\
\hline Level V & black & The worst & 1 \\
\hline
\end{tabular}

\section{Descriptive Statistics}

Table 2

Descriptive Statistics

\begin{tabular}{|l|c|c|c|c|c|}
\hline \multicolumn{1}{|c|}{ Variables } & N & Min & Maxi & Mean & $\begin{array}{c}\text { Standar } \\
\text { Deviation }\end{array}$ \\
\hline Independent & & & & & \\
\hline JRDK & 352 & 0.00 & 12.00 & 2.24 & 1.9 \\
\hline KI & 352 & 0.00 & 1.00 & 0.36 & 0.15 \\
\hline KM & 352 & 0.00 & 1.67 & 0.30 & 0.21 \\
\hline KM & 352 & 0.00 & 0.89 & 0.06 & 0.15 \\
\hline KA & 352 & 0.00 & 0.99 & 0.29 & 0.32 \\
\hline KP & 352 & 0.00 & 0.98 & 0.50 & 0.24 \\
\hline Control & & & & & \\
\hline UDK & 352 & 2.00 & 11.00 & 4.07 & 1.70 \\
\hline PPD & 352 & 0.00 & 2.00 & 0.19 & 0.34 \\
\hline KP & 352 & 0.00 & 0.67 & 0.24 & 0.15 \\
\hline KI & 352 & 0.00 & 1.00 & 0.63 & 0.25 \\
\hline EP & 352 & 0.00 & 5.00 & 1.16 & 1.49 \\
\hline CSR & 352 & 0.09 & 0.29 & 0.15 & 0.03 \\
\hline Valid N (listwise) & 352 & & & & \\
\hline
\end{tabular}

Notes: JRDK $=$ number of meetings of board of commissioners

$$
\begin{array}{ll}
\mathrm{KI} & =\text { Independent commissioners } \\
\mathrm{KA} & =\text { Audit committee } \\
\mathrm{KM} & =\text { Managerial ownership } \\
\mathrm{KAs} & =\text { Foreign Ownership } \\
\mathrm{KK} & =\text { Ownership concentration }
\end{array}
$$

Raphita Fauzyyah and Sistya Rachmawati. The Effect of Number of Meetings of The Board of Commissioners, Independent Commissioners, Audit Committee and Ownership Structure upon The Extent of CSR Disclosure 


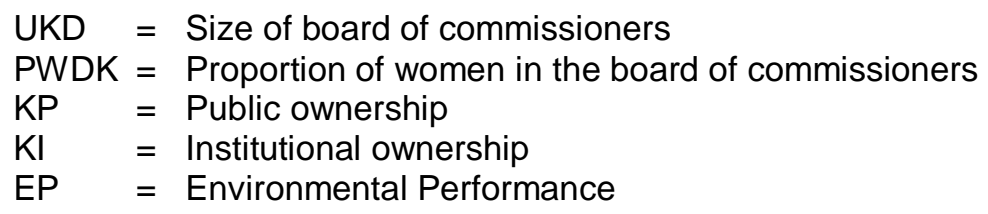

The table above has indicated that number of meetings of board of commissioners has a range of score between 0 up to 12, means of the variable is 2.24 times out of the deviation standard of 1.96. Variable of independent commissioners has indicated the value between 0 up to 1 , and mean value of 0.36 and the deviation standard of 0.155 . Audit committee (X3) has minimum score of 0 and maximum of 1.67 and or its means of 0.37 , and deviation standard of 0.21 . Managerial ownership (X4) has minimum score of 0 and maximum of 0.89 , means value of 0.06 with the deviation standard of 0.15 . Variable of foreign ownership (X5) has the minimum value 0 and maximum value of 0.99 . Means value of 0.29 with the deviation standard of 0.32 . Variable of ownership concentration has the minimum score of 0 and maximum of 0.98 . Means value of 0.50 with the deviation standard of 0.24 . The variable of size board of commissioners has the minimum value of 2 and maximum value of 11 . Means value of 4.07 and deviation standard of 1.70

The following description of the independent variables: The variable of women proportion in the board of commissioners is having the minimum value of 0 and maximum of 2 . Means value of 0.19 with the deviation standard of 0.34 . The variable of public ownership has the minimum value of 0 and maximum of 0.67 . Means value of 0.24 with the deviation standard of 0.15 . The variable of institutional ownership has the minimum score of 0 and maximum of 1 . Means value of 0.63 with the deviation standard of 0.25 . Furthermore, minimum score of the environmental performance is 0 and maximum is 5 . Means of this variable is 1.16 with the deviation standard of 1.49 . Minimum score of CSR is 0.09 and maximum of 0.29 , means value is 0.15 with the deviation standard of 0.37 .

Table 3

Result of Hypothesis Test

$\mathrm{CSR}=0.191+0.005 \mathrm{JRDK}-0.035 \mathrm{KI}+0.019 \mathrm{KA}-0.003 \mathrm{KM}+0.040 \mathrm{KA}+0.011 \mathrm{KK}+$ $0.009 U D K+0.0001$ PWDK $-0.054 \mathrm{KP}-0.116 \mathrm{KI}-0.0001 \mathrm{EP}$

\begin{tabular}{|c|c|c|c|c|c|}
\hline \multirow{2}{*}{ Variables } & \multirow{2}{*}{ Predictions } & \multirow{2}{*}{ Coefficient } & \multirow{2}{*}{$p$-value } & \multicolumn{2}{|c|}{ Collinearity } \\
\hline & & & & Tolerance & VIP \\
\hline \multicolumn{6}{|l|}{ (Constant) } \\
\hline \multicolumn{6}{|l|}{ Independent } \\
\hline $\begin{array}{l}\text { Number of meeting of board of } \\
\text { commissioners }\end{array}$ & + & 0.25 & 8.70 & 0.88 & 1.13 \\
\hline Independent commissioners & + & -0.14 & -4.66 & 0.77 & 1.29 \\
\hline Audit committee & + & 0.10 & 3.33 & 0.71 & 1.40 \\
\hline Managerial ownership & - & -0.01 & -0.37 & 0.51 & 1.94 \\
\hline Foreign ownership & + & 0.34 & 11.24 & 0.80 & 1.24 \\
\hline Ownership concentration & + & 0.07 & 2.13 & 0.61 & 1.63 \\
\hline \multicolumn{6}{|l|}{ Control } \\
\hline Size of board of commissioners & & 0.39 & 13.14 & 0.80 & 1.23 \\
\hline $\begin{array}{l}\text { Proportion of women in the board } \\
\text { of commissioners }\end{array}$ & & -0.004 & -.16 & 0.94 & 1.06 \\
\hline Public ownership & & -0.22 & -6.66 & 0.64 & 1.54 \\
\hline Institutional ownership & & -0.79 & -18.28 & 0.38 & 2.59 \\
\hline Environmental performance & & -0.004 & -0.13 & 0.85 & 1.16 \\
\hline $\mathrm{R}^{2}$ & 0.75 & & & & \\
\hline Adj. $R^{2}$ & 0.742 & & & & \\
\hline F-Statistic & 92.718 & & & & \\
\hline Prob(F-Stat) & 0,00 & & & & \\
\hline K-S & 1.27 & & & & \\
\hline DW & 1.695 & & & & \\
\hline Observation & 88 & & & & \\
\hline
\end{tabular}

Raphita Fauzyyah and Sistya Rachmawati. The Effect of Number of Meetings of The Board of Commissioners, Independent Commissioners, Audit Committee and 


\section{Classic Assumption Test}

\section{Normality Test}

Normality test is to ensure that the data collection studied by the writer is normal distributed which is identified on the plots scattering and following the diagonal line at normal probability plot. Regression data is good or positive if the distribution of data is normal or closed to the applicable normal limit. Graph of normal plot is in accordance with normality assumption test, because it has indicated that the regression model is applicable due to the plots which are scattering around the diagonal line.

\section{Multicollinearity Test}

This test is to evaluate the Variance Inflation Factor or VIF for the two independent variables which is less than 10 (none of VIF score $<10$ between the two independent variables). It is concluded that there is not any multicollinearity symptom.

\section{Autocorrelation Test}

Based on the table, data counted is 4.3, and score of Durbin Watson on the scientific writing is 1.695 . Since the score is between 1.65 and 2.335 , it explains that the autocorrelation does not occur.

\section{Heteroscedascity Test.}

The scatterplot graph of this research has indicated that the data on $Y$ axis has been scattering around 0 (null) (either above or under 0 ) and there is not any clear pattern indicated, so that, heteroscedascity is not happened.

\section{DISCUSSION}

1. The Correlation between Number of Meetings of Board Commissioners and the Disclosure of Corporate Social Responsibility.

T-test has indicated positive and significant impact of number of meetings of board commissioner on the Disclosure of Corporate Social Responsibility. The result is complied with the hypothesis which is Number of Meetings of Board Commissioners has affected the Disclosure of Corporate Social Responsibility.

2. The Correlation between Independent Commissioners and the Disclosure of Corporate Social Responsibility.

Based on t-test, it can be concluded that the Independent Commissioners have affected positively and significantly the Disclosure of Corporate Social Responsibility. This result is in accordance with the hypothesis which is the Independent Commissioners has affected the Disclosure of Corporate Social Responsibility.

3. The Correlation between Audit Committee and the Disclosure of Corporate Social Responsibility.

Based on t-test, it can be concluded that Audit Committee has affected significantly the Disclosure of Corporate Social Responsibility. This result is in compliance with the hypothesis of Audit Committee has affected the Disclosure of Corporate Social Responsibility.

4. The Correlation between Managerial Ownership and the Disclosure of Corporate Social Responsibility. 
T-test has indicated positive and significant impact of the variable of Managerial Ownership on the Disclosure of Corporate Social Responsibility. The result is in compliance with the hypothesis mentioning that Managerial Ownership has affected the Disclosure of Corporate Social Responsibility.

5. The Correlation between Foreign Ownership and the Disclosure of Corporate Social Responsibility.

T-test has concluded that there is a significant and positive impact of Foreign Ownership on the Disclosure of Corporate Social Responsibility. This result is in compliance with the hypothesis which is Foreign Ownership(outsider) has affected the Disclosure of Corporate Social Responsibility.

6. The Correlation between the Ownership Concentration and the Disclosure of Corporate Social Responsibility

T-test has indicated that positive and significant effect has happened between the Ownership Concentration and the Disclosure of Corporate Social Responsibility. It is in compliance with the hypothesis of Ownership Concentration has affected the Disclosure of Corporate Social Responsibility.

7. The Correlation between the Size of Board Commissioners and the Extent of the Disclosure of Corporate Social Responsibility

Referring to the correlation between these variables, $t$-test has determined that the significant impact has appeared between the Size of Board Commissioners and the Disclosure of Corporate Social Responsibility. It has found out that when the size of board commissioners has been becoming bigger, it is indicating the improvement of their responsibility and the success of procedures. However, the description described is more useful.

8. The Correlation between the Proportion of women in the Board Commissioners and the Extent of the Disclosure Corporate Social Responsibility.

T-test has determined that there is not any impact and crucial effect happened between the Proportion of Women in the Commissioners Board and the Extent of the Disclosure of Corporate Social Responsibility.

9. The Correlation between Public Ownership and the Extent of the Disclosure of Corporate Social Responsibility

T-test has defined that the related variable has demonstrated an important and significant impact between Public Ownership and the Extent of the Disclosure of Social Responsibility. The previous research of Prayoga \& Almilia in 2013, defined that the ownership of the shares will develop or create an effect of foreign party to execute the limitation of organizational activities management.

10. The Correlation between the Institutional Ownership and the Extent of the Disclosure of Corporate Social Responsibility

The significant effect of the Institutional Ownership has happened on the Extent of the Disclosure of Corporate Social Responsibility which is referred to the ttest result. The particular specification of the shares owned by the institution or entity will give the effect of the processing the information of financial report as it might be done according to the interest of managers internal (Wiranata \& Nugrahanti, 2013).

11. The Correlation between the Environmental Performance and the Extent of the Disclosure of Corporate Social Responsibility

The variable examination using $\mathrm{t}$-test has indicated that there is not any positive and significant impact of the Environmental Performance happened on the Disclosure of Corporate Social Responsibility. 


\section{CONCLUSION, IMPLICATION, AND LIMITATION}

\section{Conclusion}

Based on the information and the study done by the writer, it is concluded that number of meetings done by the board commissioners, independent commissioners, audit committee, foreign ownership concentration, public ownership and institutional as well as the size of board commissioners have affected the extent of the Disclosure of CSR. However, the managerial ownership, proportion women in the commissioners, and the environmental performance has not demonstrated any impact and effect on the extent of the Disclosure CSR.

\section{Implication}

Based on the description above regarding the limitation of the writer and the conclusion, the writer would like to demonstrate the following implications:

a. Based on the available information, this research can be useful for the company. However, the company is able to develop further activity of CSR.

b. The environmental CSR at the manufacturing company is actually improving the quality of the company. It is indicated that the environment factor has been affecting the manufacturing company. Referring to a lot of news mentioning that manufacturing companies have been destroying the environment, so that the companies which have been doing CSR upon the environment will be positively responded by the investor. Despite they have been improving their role to disclosure the CSR by expanding the related disclosure and being involved in other CSRs.

\section{Suggestions, Recommendation and Limitation.}

This research has a limited matter, however next researchers are expected to be able to take the lessons on it to execute more optimal research, valuable and objective research. The following limitations are as follows:

a. Population of the research has taken place for 4 years, 2014, 2015, 2016, 2017 which is the period of the research being done.

b. Samples of the research have applied 11 variables as purposive sampling which has caused the limitation of the research samples.

c. Samples of the analysis are limited only manufacturing sectors listed on BEI.

Besides that, the writer has offered some recommendations as follows:

1) In order to figure out the CSR of a company, it should have to consider number of meetings of board commissioners, independent commissioners, audit committee, managerial ownership, outsider/foreign ownership, government ownership and concentration, the size of board commissioners, proportion women in the meeting of board commissioners, public ownership, institutional ownership and the environmental performance accordingly.

2) For the writers who are interested in doing the similar research, they are expected to continue developing and exploring the research which is other factors should have to be studied instead of the factors done in this research. This research has applied the variables that have probably affected the CSR which is number of meetings of board commissioners, government party, foreign party and ownership concentration, audit committee, and controlled variables which are, the extent of board commissioners' meeting, proportion women in the commissioner meeting, institutional ownership and public as well as environment performance.

Raphita Fauzyyah and Sistya Rachmawati. The Effect of Number of Meetings of The Board of Commissioners, Independent Commissioners, Audit Committee and Ownership Structure upon The Extent of CSR Disclosure 


\section{REFERENCES}

Adjani, E D., and Rahardja, S. (2013). Diponegoro Journal of Accounting. 2 (2).

Agustino, L. (2012). Basics Principles of Public Policy Bandung: Alfabeta.

Almilia, L.S., and Prayoga, E.B. (2013). The Effect of Ownership and the Size of the company upon the Disclosure of Risk Management, Jurnal Akuntansi dan Keuangan, 14 (1), pp 1-19.

Anggita, S R. (2012). Characteristics effects of the company on the Corporate Social Responsinility Disclosure for the manufacturing listed on Indonesia stock exchange, Jurnal, 1 (1), Universitas Negeri Yogyakarta.

Anggraini, D., and Taufik, E. (2017). The Effect of the size board of commissioners and company upon the Environmental Disclosure, Jurnal Ekonomi Manajemen Dan Bisnis, 18 (2), pp 119-126.

Jenny, L. (2012). The Effect of Ownership Concentration, Size of the Company and Mechanisme of Good Corporate Governance upon the Disclosure of Annual Report of the Manufacturing Companies listed on IDX. Jurnal Berkala IImiah Mahasiswa Akuntansi, 1(1), pp 123-129.

Kusuma, D., Rusli, TA., and Darlis, E. (2014). The Effect of Corporate Governance and Company characteristis upon the Extent of Corporate Social Responsibility Disclosure in the sustainable report. Jurnal Online Mahasiswa Fakultas Ekonomi, 1(2), pp 1-13.

Marsha, F., \& Ghozali, I. (2017). The Effect of the size of audit committee, external audit, number of meetings of audit committee, number of meetings of board commissioners and the institutional ownership upon the profit management (Empirical Study of Manufacturing Companies Listed on the Indonesia Stock Exchange in 2012-2014), Diponegoro Journal of Economics, 6(2), pp 1-12.

Marsono, A. D. P. (2014). The Effect of Corporate Governance Characteristic upon the Extent of Corporate Social Responsibility Disclosure. Diponegoro Journal of Accounting, 3(1), pp 1-15.

Murwaningsari, E. (2009). The Correlation between Corporate Governance, Corporate Social Responsibility and Corporate Financial Performance within one continuum. Jurnal Akuntansi dan Keuangan, 11(1), pp 30-41.

Murwaningsari, E., and Rachmawati, S. (2017). The Influence of Capital Intensity and Investment Opportunity Set toward Conservatism with Managerial Ownership as Moderating Variable. Journal of Advanced Management Science, 5(6), pp 445451. https://doi.org/10.18178/joams.5.6.445-451

Oktariani, N. W., and Mimba, N. P. S. H. (2014). The effect of company characteristics and the environmental responsibilty on the disclosure of Corporate Social Responsibility. E-Jurnal Akuntansi Universitas Udayana, 6(3), pp 402-418.

Prayoga, E. B., \& Almilia, L. S. (2013). The Effect of ownership structure and the size of company upon the disclosure of risk management. Jurnal Akuntansi dan Keuangan, 4(1), pp 1-19.

Rachmawati, S. (2016). The effect of volunteer disclosure and corporate social responsibility disclosure upon the coefficient of profit response. Media Riset

Raphita Fauzyyah and Sistya Rachmawati. The Effect of Number of Meetings of The Board of Commissioners, Independent Commissioners, Audit Committee and 
Akuntansi, Auditing, dan Informasi, 16 (2), 141-160.

Saifi, M., and Sarafina, S. (2017). The Effect of good corporate governance upon the financial performance and company value (Study of State-Owned Enterprises (SOEs) Registered on the Indonesia Stock Exchange for the 2012-2015 Period), Jurnal Administrasi Bisnis, 50(3), pp108-117.

Sari, R. A. (2012). The effect of company characteristis upon corporate social responsibility closure at the manufacturing companies listed on the Indonesia Stock Exchange. Jurnal Nominal, I (I), pp 124-140.

Wiranata, Y. A., and Nugrahanti, Y. W. (2013). The Effect of ownership structure upon the manufacturing companies profitability in Indonesia. Jurnal Akuntansi dan Keuangan, 15 (1), pp 15-26. https://doi.org/10.9744/jak.15.1.15-26

Raphita Fauzyyah and Sistya Rachmawati. The Effect of Number of Meetings of The Board of Commissioners, Independent Commissioners, Audit Committee and Ownership Structure upon The Extent of CSR Disclosure 
The Accounting Journal of BINANIAGA Vol. 03, No. 02, December 2018

PISSN: $2527-4309$

EISSN: $2580-1481$

This page intentionally be emptied.

Raphita Fauzyyah and Sistya Rachmawati. The Effect of Number of Meetings of The Board of Commissioners, Independent Commissioners, Audit Committee and Ownership Structure upon The Extent of CSR Disclosure 